SAKAI SAMBAYAN — Jurnal Pengabdian kepada Masyarakat

\title{
Pengolahan Rumput Laut (Euchema sp) Menjadi Produk Pengharum Ruangan Aromaterapi di Desa Legundi Kecamatan Ketapang Kabupaten Lampung Selatan
}

\author{
Yuli Ambarwati $^{1 *}$, Syaiful Bahri ${ }^{1}$, Notiragayu ${ }^{2}$, Yessi Mulyani ${ }^{3}$ \\ ${ }^{1}$ Jurusan Kimia FMIPA Universitas Lampung \\ ${ }^{2}$ Jurusan Matematika FMIPA Universitas Lampung \\ ${ }^{3}$ Jurusan Teknik Elektro FT Universitas Lampung \\ Penulis Korespodensi : yuli.ambarwati@fmipa.unila.ac.id
}

\begin{abstract}
Abstrak
Desa Legundi merupakan salah satu desa yang ada di kecamatan Ketapang, Kabupaten Lampung Selatan. Sebagian penduduknya bermata pencaharian sebagai nelayan. Sebagian dari nelayan tersebut mendapat penghasilan dari budidaya rumput laut. Rumput laut yang dibudidayakan adalah jenis Euchema sp baik varitas spilosom maupun katonii. Harga rumput laut yang fluktuatif membuat para nelayan sering kurang bergairah dalam membudidayakan rumput laut. Salah satu sebabnya karena selama ini para nelayan menjual produk mereka sebatas sebagai rumput laut saja. Mereka belum melakukan diversifikasi produk untuk meningkatkan nilai tambah dari rumput laut itu sendiri. Untuk itu tim Pengabdian Masyarakat dari Jurusan Kimia, dimana personilnya merupakan gabungan dari jurusan Matematika dan Teknik Elektro telah melaksanakan kegiatan pengabdian dengan tema "Pengolahan Rumput Laut (Euchema sp. Menjadi Produk Pengharum Ruangan Aromaterapi”. Adapun tujuan dari kegiatan pengabdian kepada masyarakat ini adalah sosialisasi dan pelatihan pembuatan pengharum ruangan aromaterapi yang berbahan dasar rumput laut. Dengan pelatihan ini diharapkan para nelayan dapat membuat produk aromaterapi dari bahan dasar rumput laut. Hasil kegiatan menunjukkan peningkatan rerata pengetahuan masyarakat sebanyak $60 \%$ dari semua komponen TIK yang diukur. Namun demikian, besarnya peningkatan persentase pengetahuan belum sebanding dengan kenyataan di lapangan yang menunjukkan masih sedikitnya masyarakat yang berpartisipasi dalam pengolahan rumput laut menjadi produk aromaterapi secara mandiri. Karena itu ke depannya masih diperlukan usaha yang terus menerus untuk meningkatkan kesadaran masyarakat terhadap diversifikasi pengolahan rumput laut menjadi produk aromaterapi secara mandiri.
\end{abstract}

Kata kunci: rumput laut, Euchema sp, aromaterapi, Legundi

\section{Pendahuluan}

Desa Legundi merupakan desa pertanian, maka sebagian besar penduduknya bermata pencaharian sebagai petani. Meskipun sebagian besar penduduknya sebagai petani, namun desa Legundi terkenal sebagai satu penghasil rumput laut di propinsi Lampung, bahkan rumput laut menjadi produk unggulan dari desa Legundi. Nelayan merupakan matapencaharian pokok sebagian masyarakat Desa Legundi dan jumlah populasi nelayan terus meningkat setiap tahunnya, hal ini karena pekerjaan nelayan hanya bermodalkan tenaga. Nelayan yang hidup di daerah pesisir pantai sangat dipengaruhi dengan kondisi alam terutama angin, gelombang dan arus laut, sehingga aktivitas penangkapan ikan tidak berlangsung sepanjang tahun. Pada periode tertentu nelayan tidak melaut karena angin kencang, gelombang besar dan arus laut yang kuat. Kondisi alam seperti ini disebut musim paceklik yaitu dimana musim nelayan tidak beraktivitas sama sekali dan membuat pendapatan nelayan menjadi rendah dan tidak menentu. Kondisi tersebut membuat para nelayan tangkap ikan berubah haluan untuk menjadi nelayan budidaya rumput laut. Para nelayan Desa Legundi mecapai puncak produksi rumput laut antara tahun 2005- 2011 (Lampost.co, 2017). Potensi perairan, kelayakan budidaya, teknologi budi daya yang mudah, masa tanam pendek, dan ketersediaan tenaga kerja setempat merupakan modal potensial bagi perkembangan usaha budi daya rumput laut di perairan desa Legundi. Namun pada kenyataannya jumlah pembudidaya yang tertarik pada usaha budidaya rumput laut semakin menurun. Hal ini 
disababkan oleh karena harga rumput laut yang fluktuatif dan cenderung menurun.

Untuk membantu memberikan solusi dari permasalahan yang dihadapi oleh para nelayan di Desa Legundi, maka tim Pengabdian Masyarakat dari Jurusan Kimia dengan anggota personil dari Jurusan Matematika dan Teknik Elektro telah melaksanakan pengabdian dengan tema cara pembuatan produk pengharum ruangan aromaterapi berbahan dasar rumput laut. Adapun tujuan dari kegiatan tersebut adalah memberikan pelatihan dan penyuluhan kepada para nelayan tentang manfaat rumput laut selain sebagai bahan makanan,yakni dapat dimanfaatkan untuk membuat pengharum ruangan aromaterapi. Kegiatan ini juga untuk membina dan membantu masyarakat nelayan Desa Legundi dalam mempelajari cara pembuatan produk pengharum ruangan aromaterapi berbahan dasar rumput laut. Selain itu juga untuk meningkatkan pengetahuan, ketrampilan dan keahlian masyarakat nelayan Desa Legundi dalam hal manajemen pembuatan produk pengharum ruangan aromaterapi berbahan dasar rumput laut.

Dengan kegiatan pengabdian masyarakat ini diharapkan dapat meningkatkan pengetahuan, skill dan kemampuan para nelayan budidaya rumput laut dalam hal diversifikasi produk menjadi pengharum ruangan aromaterapi. Setelah masyarakat nelayan mampu membuat produk pengharum aromaterapi maka memungkinkan terbukanya lapangan pekerjaan bagi masyarakat Desa Legundi. Pada akhirnya kegiatan ini diharapkan dapat meningkatkan kesejahteraan masyarakat nelayan Desa Legundi.

\section{Metode Kegiatan}

Pelaksanaan kegiatan pengabdian kepada masyarakat dimulai dengan melakukan survei ke lapangan, melakukan komunikasi pada pamong desa, ketua kelompok nelayan dan tokoh masyarakat di Desa Legundi Kecamatan Ketapang Kabupaten Lampung Selatan. Persiapan dilanjutkan dengan mengurus surat tugas dari LPPM, merencanakan materi yang akan diberikan, pembagian kerja diantara tim pelaksana, dan mengadakan kesepakatan waktu kegiatan dengan kelompok nelayan ikan dan rumput laut Sinar Legundi di lingkungan tersebut.

Pelaksanaan kegiatan pengabdian kepada masyarakat dilakukan dalam beberapa bentuk kegiatan yaitu ceramah, demonstrasi, diskusi kelompok dan evaluasi. Metode ceramah digunakan untuk menyampaikan materi secara lisan tentang pendalaman pengetahuan tentang rumput laut, yang dimulai dari penyuluhan tentang jenis jenis rumput laut, dilanjutkan dengan materi tentang pengolahan berbagai produk olahan rumput laut, materi tentang aromaterapi. Materi inti tentang pengolahan rumput laut menjadi pengharum ruangan aromaterapi. Kegiatan dilanjutkan dengan demonstrasi, metode ini digunakan untuk mempraktikan bagaimana cara mengolah rumput laut menjadi pengharum ruangan aromaterapi. Dalam tahap pelaksanaan ini juga diberikan contoh pengharum ruangan yang dihasilkan dari rumput laut untuk memotivasi para nelayan. Diskusi kelompok dilakukan agar warga lebih memahami materi yang diberikan dan memberikan kesempatan kepada peserta untuk lebih aktif, serta memberikan kesempatan berkembangnya komunikasi multi arah sehingga tanggapan dan aspirasi setiap anggota kelompok dapat tertampung dengan baik.

Kegiatan evaluasi dilakukan untuk mengetahui efektivitas kegiatan pengabdian. Hasil evaluasi ini diharapkan akan memberikan masukan untuk perbaikan pada kegiatan berikutnya. Evaluasi juga dilakukan untuk mengetahui tingkat minat atau perhatian peserta pada pelaksanaan kegiatan. Evaluasi kegiatan dilakukan dengan mengadakan pre-test dan post-test untuk membandingkan beberapa parameter ukur yang yang meliputi tentang peningkatan minat, pengetahuan, kemampuan, kesadaran, dan ketrampilan peserta untuk mengolah rumput laut menjadi pengharum ruangan aromaterapi. Pengolahan rumput laut menjadi pengharum ruangan aromaterapi berbasis partisipasi masyarakat membutuhkan usaha yang berkelanjutan. Karena itu diperlukan pendampingan agar proses pengolahan rumput laut menjadi pengharum ruangan aromaterapi ini tidak berhenti setelah kegiatan penyuluhan atau pun demonstrasi, tapi terus berlangsung dan kemudian diharapkan akan terjalin kerjasama membentuk wirausahaan yang produktif untuk meningkatkan kesejahteraan warga sehingga pengelolaan rumput laut menjadi pengharum ruangan aromaterapi di daerah ini dapat menjadi salah satu role model diversifikasi pengelolaan rumput laut di Lampung Selatan bahkan di Propinsi Lampung. Kegiatan pendampingan dan survei lapangan dilakukan pada minggu ke 1 dan minggu ke 3 setelah kegiatan dilaksanakan. 


\section{Hasil dan Pembahasan}

Sebelum kegiatan pelatihan dilakukan serangkaian pre test untuk mengetahui pemahaman peserta terhadap pertanyaan yang diajukan yang berkaitan dengan rumput laut, permasalahan dan pengolahannya. Pertanyaan pada pre test juga merupakan pertanyaan pada post test dalam rangka membandingkan hasil kegiatan pelatihan dengan menyusun pertanyaan TIK (tabel 1) yang sesuai pada pre test dan post test. Materi yang disampaikan pada kegiatan pengabdian ini berkaitan dengan substansi pertanyaan yang diajukan di atas yang meliputi pengetahuan tentang rumput laut dan permasalahannya dan diversifikasi produk yang dihasilkan. Melalui kegiatan ini diharapkan tumbuhnya kesadaran masyarakat untuk mengolah rumput laut menjadi produk pengharum ruangan aromaterapi. Sehingga pada akhirnya dapat meningkatkan kesejahteraan para nelayan di Desa Legundi. Hasil pre test dan post test dapat dilihat pada Tabel 2.

Tabel 1. Komposisi materi evaluasi pada pre test dan post tes

\begin{tabular}{|c|c|c|c|c|}
\hline No & Tujuan Instruksional Khusus (TIK) & $\begin{array}{l}\text { Butir } \\
\text { soal }\end{array}$ & $\begin{array}{c}\text { Jumlah } \\
\text { soal }\end{array}$ & $\begin{array}{c}\text { Prosent } \\
\text { ase }\end{array}$ \\
\hline 1 & $\begin{array}{l}\text { Mengetahui pemahaman peserta } \\
\text { tentang rumput laut dan } \\
\text { permasalahannya }\end{array}$ & 1,2 & 2 & 20 \\
\hline 2 & $\begin{array}{c}\text { Mengetahui pengetahuan peserta } \\
\text { tentang kandungan nutrisi dalam } \\
\text { rumput laut }\end{array}$ & 3,4 & 2 & 20 \\
\hline 3 & $\begin{array}{l}\text { Meningkatkan pengetahuan peserta } \\
\text { tentang teknik pembuatan produk } \\
\text { aromaterapi berbahan dasar rumput } \\
\text { laut }\end{array}$ & 5,6 & 2 & 20 \\
\hline 4 & $\begin{array}{l}\text { Meningkatkan pengetahuan peserta } \\
\text { tentang manfaat aromaterapi }\end{array}$ & 7,8 & 2 & 20 \\
\hline 5 & $\begin{array}{c}\text { Meningkatatkan pengetahuan } \\
\text { peserta tentang penggunaan } \\
\text { aromaterapi }\end{array}$ & 9,10 & 2 & 20 \\
\hline
\end{tabular}

Tabel 2. Perbandingan hasil pencapaian TIK pada pre test dan post test

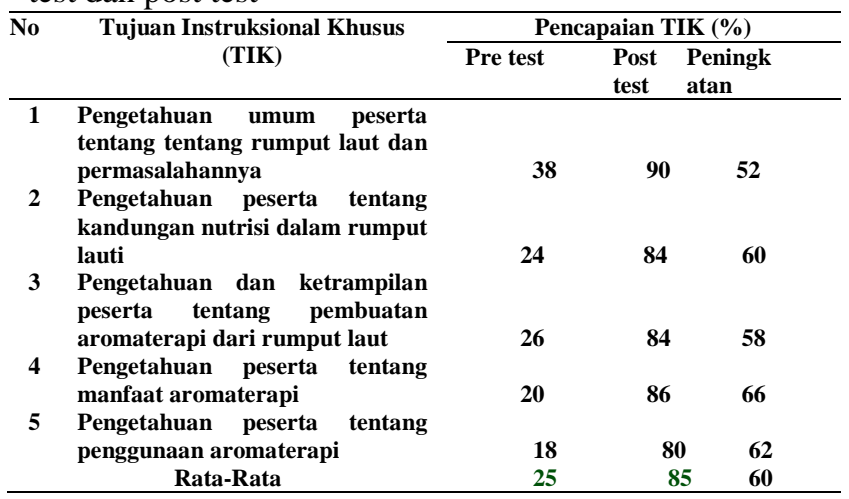

\section{Analisis Evaluasi Hasil Pengabdian}

Kegiatan ini dilakukan untuk meningkatkan pengetahuan dan menumbuhkan kesadaran masyarakat tentang pentingnya diversifikasi olahan rumput laut. Selama ini para nelayan menjual hasil panen hanya sebatas rumput laut saja. Belum pernah dilakukan variasi atau diversifikasi menjadi produk yang lain. Dari hasil kegiatan ini dapat dilihat besarnya animo peserta untuk mengolah rumput laut menjadi produk aromaterapi, seperti yang ditunjukkan oleh hasil pencapaian TIK pada tabel 2.

Data pada Tabel 2 menunjukkan bahwa telah terjadi peningkatan TIK pada setiap peserta setelah kegiatan pengabdian ini dilaksanakan. Pada Tabel 2 dapat dilihat bahwa masing-masing TIK telah mengalami kenaikan dengan kenaikan rata-rata sekitar 60\%. Hal ini menunjukkan bahwa pengetahuan masyarakat tentang rumput laut dan permasalahannya serta pengolahannya telah meningkat secara signifikan. Dengan peningkatan pengetahuan ini maka kesadaran masyarakat juga akan tumbuh bahwa diversifikasi pengolahan rumput laut memerlukan partisipasi dari setiap warga.

Evaluasi juga dilakukan dengan melakukan pendampingan dan survei lapangan di lokasi warga tinggal. Berdasarkan hasil survei yang dilakukan pada minggu ke 1 dan minggu ke 3 setelah sosialisasi maka terlihat beberapa warga sudah mulai melakukan pengolahan rumput laut menjadi produk pengharum aromaterapi.

Kegiatan selama proses pengabdian dapat dilihat pada foto-foto kegiatan berikut ini.

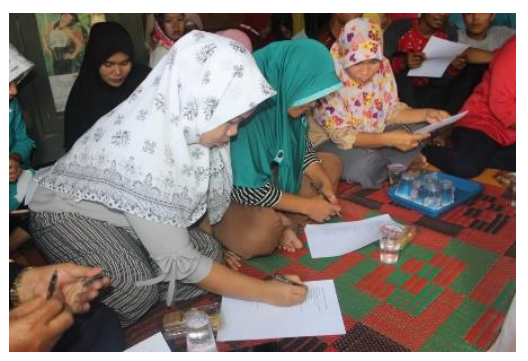

Gambar 1. Peserta sedang mengerjakan pre tes 


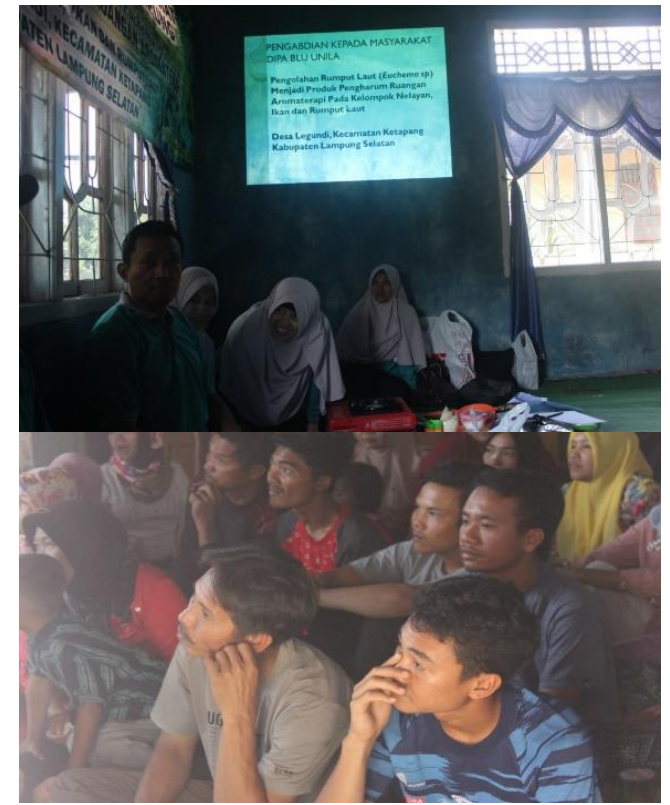

Gambar 2. Para peserta sedang memperhatikan penjelasan oleh tim

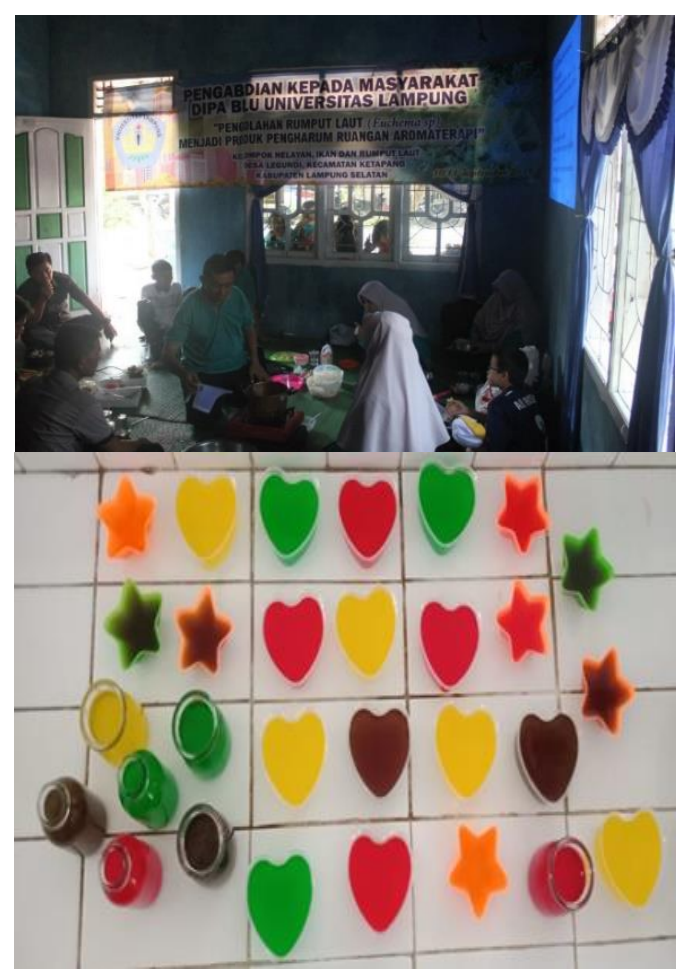

Gambar 3. Demo pembuatan aromaterapi

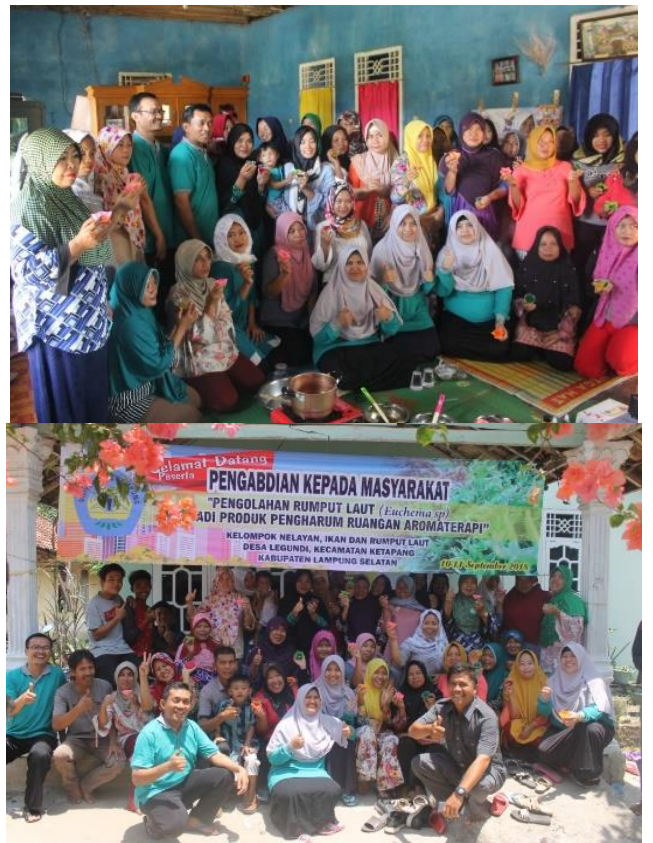

Gambar 4. Hasil pelatihan

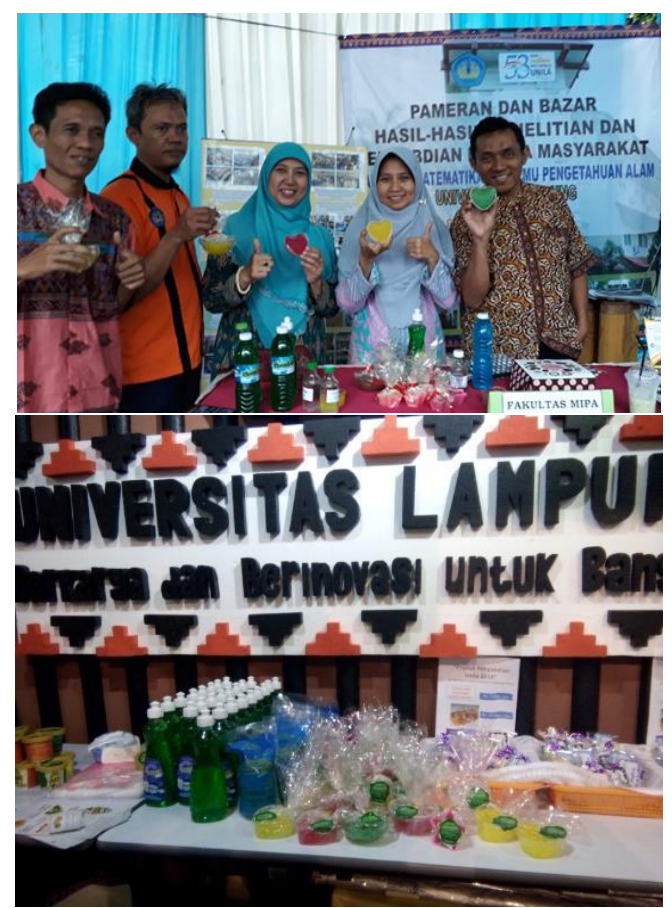

Gambar 5. Hasil pelatihan siap dipasarkan

\section{Kesimpulan}

Dari hasil kegiatan pengabdian masyarakat ini, pengetahuan warga nelayan di Desa Legundi meningkat tentang budidaya rumput laut dan permasalahannya, mengetahui bahan untuk pembuatan aromaterapi, dan pengolahan rumput laut menjadi produk pengharum ruangan aromaterapi dan telah meningkat rata-rata $60 \%$. Pengolahan rumput laut menjadi produk 
pengharum ruangan aromaterapi sebagai peluang untuk menambah pendapatan sekaligus menjaga produktifitas penanaman rumput laut yang fluktuatif akibat harga yang naik turun.

\section{Ucapan Terima Kasih}

Kami ucapkan terimakasih kepada LPPM UNILA atas bantuan dana Pengabdian DIPA Senior 2018 sehingga pengabdian ini dapat terlaksana dengan baik. Kami juga ucapkan terima kasih kepada Kepala Desa dan kelompok tani Nelayan dan Ikan Desa Legundi kecamatan Ketapang Lampung Selatan.

\section{Daftar Pustaka}

Hasanah. U, 2013, Analisis Kesesuaian Perairan Untuk Lokasi Budidaya Rumput Laut Euchema cotinii di Perairan Kabupaten Sajoanging Kabupaten Wajo. Skripsi Universitas hasanudin.
Kiswanti, 2009, Pemanfaatan Karagenan yang ditambahkan Minyak Sereh Wangi Pada Formula Gel Penolak Nyamuk (Culex quinqifastiacus). Skripsi FP IPB.

Neksidin, 2013, Studi Kualitas Air Untuk Budidaya Rumput Laut (Kappaphycus alvarezii) di Perairan Teluk Kolono Kabupaten Konawe Selatan. Jurnal Mina Laut Indonesia Vol . 03 No.12 September 2013 (hal. 147-155).

Sinatrya, M., 2009, Sifat Organoleptik Aromaterapi Transparan Dengan Penambahan Madu, Skripsi, Institut Pertanian Bogor, Bogor.

Wibowo, L. Fitriani, Evi., 2012, Pengolahan Rumput Laut (Euchema sp) Menjadi Serbuk Minuman Instan, Tugas Akhir, Politeknik Negeri Pontianak.

Van de Velde F, De Ruiter GA, 2005, Carrageenan. Steinbuchel (dalam Polysacharides and Polyamides in the Food Industry. Vol.1. 